\title{
Transnationalism and the Caribbean Community in the UK: Theoretical Perspectives
}

\author{
Ellen Quirke ${ }^{*}, 1$, Robert B. Potter ${ }^{1}$ and Dennis Conway ${ }^{2}$ \\ ${ }^{I}$ Department of Geography, School of Human and Enviromental Sciences, University of Reading, Whiteknights, P.O. \\ BOX 227, Reading RG6 6AB, UK \\ ${ }^{2}$ Department of Geography, Indiana University, Student Building 120, 701 E. Kirkwood Avenue, Bloomington, IN \\ 47405-7710, USA
}

\begin{abstract}
The past twenty years have seen the emergence and growth of transnationalism as a concept to describe new immigrant identities and communities in a globalised world and international scholars of migration have begun to recognise its significance in helping to explain and better understand contemporary international migration flows, new immigrant identities and communities. This paper first examines the many diverse theoretical perspectives on transnationalism that have emerged in recent decades; then we narrow the optic to consider its persistence and degrees of adoption/adaptation amongst the 'next generations' - the 1.5-, second- and third- generations, with particular reference to the British-Black Caribbean case. From the admittedly limited research conducted to date, findings on second-generation return migration to the Caribbean from the UK suggest that for a cohort of British-born individuals, transnational practices are 'alive and well' among British-Caribbean communities. To follow up on such preliminary conclusions, we advocate more research on the transnational practices, inter-generational transfers and intention to return among the 1.5-, secondand third-generation Black Caribbean communities in situ in the UK.
\end{abstract}

Keywords: Transnationalism, Black British, Caribbean community, Return migration, Second-generation.

\section{INTRODUCTION}

As globalization becomes more pervasive and as advances in the fields of communication and transport influence peoples' abilities and opportunities to act globally, social interactions, communities, lives and livelihoods, socio-spatial fields and perceptual ranges have become more widely dispersed and linked across borders and between nation-states. As migrants engage in more frequent travel to, and from, both their receiving country and their country of origin, ideas, cultures and, increasingly, people are being 'transferred and transformed' across borders. Over the past twenty years, scholars of international migration have increasingly begun to recognise that international migrants maintain links and ties with their countries of origin in ways and means not practiced in earlier times [1-4]. In more and more cases, contemporary emigrants, immigrants and circulators belong to transnational communities with globalto-local links that grow and diversify in their reach and scope. These links have the potential to privilege such participants, by helping them enrich their stocks of social, cultural and human capital and to broaden their fields of opportunity and interaction, both nationally and transnationally [3, 5-10].

Accordingly, scholars of international migration have turned to the notion of 'transnationalism' to conceptualise what many see as new immigrant identities and communities

*Address correspondence to this author at the Department of Geography, School of Human and Enviromental Sciences, University of Reading, Whiteknights, P.O. BOX 227, Reading RG6 6AB, UK;

E-mail: e.k.quirke@reading.ac.uk
[4, 11-19]; (although see Waldinger and Fitzgerald [20] for a cautionary critique). Over the past two decades, transnationalism as a conceptual framework has grown rapidly and, as it continues to strengthen and widen its empirical base, is generating more interest and excitement as an international migration research topic with considerable policy relevance. This is clearly demonstrated by the growing corpus of literature on transnationalism by anthropologists, geographers, sociologists and others, who are no longer just examining transnationalism in Europe and North America, but farther afield in the global South - in East Asia, the Pacific and Oceania (see, for example, Baio [21]; Connell and Conway [22]; Conway and Potter [23]; Hugo [24]; Iredale [25]; King and Connell [26]; Yeoh and Willis [27]).

Transatlantic perspectives originally held sway, especially in US-based discourse and related research, with Asia-Pacific perspectives following soon thereafter [28]. However, in contemporary scholarship, the geographic reach of enquiry into transnationalism has widened considerably and conceptual depth has been strengthened [29-34] thereby providing exciting opportunities for even greater crosscultural, comparative generalizations. In addition, the widening of the use of the early concept of diaspora [35-37] to incorporate migration situations that are not primarily associated with forced displacements, flight, exile and forced dispersals, has brought even more interdisciplinary attention to transnational, 'cross-border' interconnectedness and multiple senses of self and community [13, 38]. Increased interest in migration-development relations in policy-making circles, both at the national and global levels (for example, the UN's 2005 Global Commission on International 
Migration Report [39]), has added further to the relevance of the study of transnationalism [40].

One consequence of the rapid growth in transnationalist thought over the past thirty years or so is a new found deeper appreciation of the experiences, identities and positions of immigrants and their offspring - the so-called 'next generations'. Assimilationist-led studies on the second- and third-generation, which tended to view their subjects' experiences narrowly as indicators of their degrees of adjustment to the host society, gave way to more nuanced transnationalist appraisals of the totality of links and connections which the 'next generations' choose to forge, maintain and break with both their ancestral homeland and their host society. It is, therefore, pertinent to look at how the growth of transnationalism as a concept has influenced our understanding of these 'next generations' across the globe and debate whether or not, for all its emphasis on the individual identity and experience, transnationalism has, in fact, deepened our understanding of the migration patterns of the second-generation. This paper explores the emerging literature on transnationalism, and the varieties or 'flavours' of transnationalism which have been put forward as modes to interpret transnational practices, behaviours and activisms, as well as the wider landscape of cultures, spaces and sites where transnationalism is occuring. Next, the paper maps out the (necessarily blurred and confused) effects these overlapping waves of transnationalist thought have had upon research in the field, by following the deployment of transnationalist perspectives over the past thirty years in research upon one community: the Caribbean community in the UK. Finally, it argues that, as new waves of transnationalist thought have broadened the understanding of what constitutes transnational behaviour, the field of transnational enquiry within the community has also broadened, and it traces the change in focus of transnationalist studies from first-generation migrants, to second- and third- generation return migrants, and then to the second- and third- generation in situ.

\section{UNEVENESS IN THE CONCEPTUAL DEVELOP- MENT OF THE NOTION OF TRANSNATIONALISM: "CRITICAL REVISIONS AFTER A SHAKY START"}

\section{An 'Unbounded' Notion}

During the early 1970s, scholars in the field of international relations coined the term 'transnationalism' to describe the growth of non-state institutions and governance regimes that act across national boundaries [13]. By the end of the next decade, the term had been adopted by a group of cultural anthropologists led by Glick Schiller et al. [41], who examined transnationalism among US-destined immigrants and embarked on a theoretical exploration of the relations between the emerging presence of globalisation forces and this apparently new immigration phenomenon. Prior to this, earlier work on migrants and their descendents had been broadly dominated by an assmiliationist framework, which suggested that once migrants settled into their new host countries, they would generally sever links with their countries of origin. It was assumed that migrants would 'assimilate' into their received countries [42, 43]. This idea of migrants assimilating into their new host countries was also extended to the children of these migrants - the second- generation. At this juncture it is important to note that assimilation has always held more sway in North America largely based on an American experience during an earlier period of mass immigration. Outside of this social and political arena, the concept has never really covered ground in Europe and in the UK, where scholars have largely tended to concentrate their writings around the ideas of 'hybridity' and 'creolization' and "syncretic cultures bringing together white and black" ([44] p. 126).

Over the years, assimilation has lost ground in the debate on international migration to transnationalism. Transnationalism has now been put forward as a more appropriate way of understanding contemporary migration and even as a substitute for assimilation. It can be argued that transnationalism has allowed scholars of international migration to form a much deeper understanding of migrants and their migration patterns and ties with the ancestral homeland. As a consequence, to strengthen their theoretical construct, Glick Schiller et al. [41] turned to concepts derived from dialectical anthropology [45] using the study of structure, cultural processes and human agency to examine the global forces that shape the cultural practices and subjectivities of transmigrants. Drawing upon Anderson's ([46] p. 15) ideas about "a nation as an imagined political community", they viewed this cross-border influx of transmigrants as a process of de-territorialization resulting from the widening of these new immigrants' social fields beyond nation-state borders. If these new immigrants were morphing into new transnationals [47], they were expected to reconstruct their social fields, and narrate how their realised social identities and practices affected their nationstates of origin and destination. Transnationalism was an emerging contemporary migration process that challenged nation-state sovereignty and confounded national identity formation [41, 47]. Transnationalism appeared to be, or was becoming, a new type of experience for US immigrants, "reflecting an increasing and more pervasive global penetration of capital" ([48] p. 24).

This early 'cultural' interpretation drew on the experiences of immigrants from several global regions - for example, Grenada, St. Vincent and the Grenadines, Haiti and the Philippines. Through their own admission, as involved observers and participants, Glick Schiller et al. assessed and interpreted transnationalism through their own North American, immigrant cultural lenses. It was scarcely surprising, therefore, that the transnational accounts they 'narrated' typically privileged American, social and cultural constructions that are unique to the metropolitan milieu of the host United States, and the global city of New York [49, 50]. This 'insider' perspective, accepted without question that transmigrant identities were a derivative of new immigrants' (selective and segmented) assimilation to the metropolitan ways of life, cultural mores and individualized lifestyles of New York City and the United States. Underlying such a conceptualization was the assumption that transnationalism would bring about an inevitable assimilation to North American practices, values and lifestyles, even as the people involved are living transnational existences "betwixt and between" two (or more) nation-states. What emerged was an account that situated transnational behavior in an 'imagined community' that was a "look-a-like" or hybrid-variant of New York 
City's materialistic, individualistic, metropolitan 'consumerscape culture'. The 'imagined communities' of these transmigrant's homelands were scarcely factored into the nexus of explanation, except as 'distant shores' that they left behind, with memories fading and diminishing as time passed.

On the one hand, as North American/New York Citybased cultural anthropology/post-modern constructs, Glick Schiller et al's notions are not easy to apply in other globalto-local contexts. On the other hand, this embryo transnational construct denies (or overlooks) the variations in migrants' pragmatic adjustments to living in a world that is not "home". Also, the construct does not recognize, or incorporate into its explanation, the global-to-local influences on the migrants' everyday life practices and experiences. This limits possibilities for drawing together common experiences and identifying underlying processes of transnational adjustments. As a result, it is difficult for this early notion of transnationalism to explain authoritatively what might be the material circumstances of peoples' everyday lives, or to help identify the relative importance of different cultural, social, political, and economic processes in both the "home" and "away" worlds.

For all the above reasons, and because of the limited degree of empirical substantiation that accompanied the conceptualizations in this anthropological sortie, we argue that this early transnational concept sheds little light on the process of international migration itself. In particular, it fails to address how geographic mobility as one among many transnational practices may be linked to social processes of adjustment, adaptation, identity-formation, family relations and life-course transitions. If the spatial and temporal dimensions of transmigrants' life-courses are to be given their place in a fuller explanatory construct, the range of mobility options open to transmigrants must be factored into the explanation, along with the durations of sojourn during immobility stages.

Merely positioning such transmigrants in terms of deconstructed 'imagined communities' - that are by cultural reference and cultural senses, identities and social 'spaces' located in metropolitan USA - is not sufficient. It does not ground the behaviours, experiences and social relationships in the 'betwixt and between' transnational worlds that contemporary transnational migrants from all over the globe have lived in, and are actually living in, as they move through their stages of life, and are those they identify with, or will in the future. Such 'cultural abstractions' of imagined social spaces, of symbolic valuations, and of bi-national identity formation do not help us understand the ways in which movements interrupt, or alter, life-course transitions. They do not explain how immobility and temporary sojourning intervene, truncate or modify outcomes, and how such 'time-space distancing' of people brings about changes in power relations, social and familial networks, relations and obligations, and differentiates migrants' labor force experiences. Thus, Glick Schiller et al's proposed construction of transnationalism falls short when it comes to understanding how a wide range of mobilities influence the material lives of migrants. It does not consider the historical, geographical and material conditions under which migrants choose their international mobility strategies, and the social, political and economic consequences of their circuits of international mobility between "home" and "host" milieus. Fortunately, others would soon address many of these shortcomings and widen the empirical realm beyond North America - thereby contributing to a more thoughtful, careful and clearer explanation of this emerging phenomenon with a stronger theoretical basis and wider empirical support.

\section{AN EMERGING FIELD OF ALTERNATIVE CONCEPTUALIZATIONS}

One debate that was soon convincingly settled concerned the newness of transnationalism and its 'exceptionalist' association with globalization, with authorities pointing out that US immigration history was replete with cases where the maintenance of ties to original homelands were rarely completely severed, but were to be freely expected [51-55]. Yet, despite early criticism, the transnational concept survived and prospered, in part because emerging "schools of thought" overlapped in their conceptualizations, modes and meanings, rather than diverging and differentiating themselves from each other.

Earlier Vertovec [17] had reviewed the field and judged it as dealing with 'variegated phenomena' with studies covering "transnational... communities, capital flows, trade, citizenship, corporations, inter-governmental agencies, nongovernmental organisations, politics, services, social movements, social networks, families, migration circuits, identities, public spaces, public cultures" (p. 448). 'Conceptual muddling' was his considered assessment. He identified six themes as a way of seeking to understand the term 'transnationalism': transnationalism as a social morphology, a type of consciousness, a mode of cultural reproduction, an avenue of capital, a site of political engagement, and as a reconstruction of 'place' or 'locality'. Vertovec [17] further suggested that transnationalism does not only refer to social space but also to consciousness, which suggests that if groups are transnational in social space they must therefore possess a transnational consciousness, or transnational imagery that reshapes "a multitude of forms of contemporary cultural production" ([17] p. 451). In Vertovec's [17] opinion, transnationalism is to be seen as "an umbrella concept for most of the globally transformative processes and developments of our time" (p. 459).

Specifically focusing on some of the conceptual disagreements in the emerging literature on transnationalism, several approaches can be singled out and compared, as reviewed below under nine headings. For the purpose of this paper, the individual approaches can be divided into two broad categories - those which focus on transnational practices, behaviours and activities, and those that are more concerned with the cultures, spaces and sites where transnationalism occurs.

\section{Transnational Practices, Behaviours and Activities}

(1) Portes, Guarnizo and Landolt ([15] p. 221-225), and others of like persuasion argued for a very clear cut definition of transnationalism, one which requires activities to have "regularity, routine involvement and critical mass". In these authors' earliest conception, immigrants actually lived in and between two 
countries, and their resultant migrant practices could be either transnational or not, depending on their repetitiveness, regularity and longevity. In their opinion, three types of transnationalism could occur: (1) economic, (2) political and (3) socio-cultural; all requiring sustained and regular long-term contact across borders to be truly transnational.

A second approach emphasizes 'transnational practices', as opposed to a 'transnational condition of being', which replaces the fine line associated with transnationalism with a continuum, such that the regular sustained trans-state practices underscored by Portes et al. [15] shade off into something more erratic and intense [56]. And, further difficulties were found in the conceptualization of cross-border activities that interact with transnational experiences.

Another approach presented a formulation labelled and embellished as 'transnational urbanism', which contrasted transnational capitalist institutions' power as 'globalization from above' with transnational migrants' activism as 'globalization from below' [57, 58]. Transnational urbanism, therefore, offered a view from below - from inner city neighborhoods, enclaves in the suburbs, multi-ethnic communities, minority spaces and places - in which transnational migrants and their cross-border networks "forge the translocal connections and create the translocalities that increasingly sustain new modes of being-in-theworld," ([59] p. 237). It might very well be characterized as a "globalization from below" [60], but as an 'urban social movement' it is not sufficiently powerful and coordinated to serve as a competitor or alternative to the many geo-political and geo-economic forces that constitute "globalization from above", nor to reflect neoliberal capitalism's dictates, power and authority. In Giddensian [61] terms, transnational urbanism facilitates agency and the incubation of limited empowerment and communal authority in, and among, transmigrant communities, but it does not counteract global capitalism's force as the dominant, and dominating, macro-structural determinant of contemporary urban systems dynamics.

Scholars of so-called 'Global cities' have also contributed to diversification in the study of transnationalism, in their examinations of 'transnational elites'. Within the body of literature on skilled labour migration, the circulation of a transnational group of highly skilled, highly paid professional, managerial and entrepreneurial corporate elites has been afforded considerable attention [62-65]. In large part, this is because of these elites' mobility and willingness to move temporarily, both within transnational corporate structures, or more independently between them and to different global cities, to take advantage of career advancement opportunities, build their stocks of international business experience, and more generally to improve their material standards of living and their wealth. Indeed, highly skilled migrants represent an increasingly large component of global migration flows in the post-1980s era of globalization, as the 'internationalisation' of professions has continued apace $[66,67]$.

Conradson and Latham [68] have further pointed out that, as well as transnational corporate elites there are middle-class transnational migrants who also circulate and form global networks, such as professional health workers, nurses, English-as-asecond-language (ESL) teachers, civil and electrical engineers, IT specialists, artists and performers. Following professional careers in which short-term contract-assignments abroad can represent a welcome broadening of experience and a highly profitable remunerative return for these relatively young, and relatively independent young professionals, such modern-day transnational 'workers without frontiers' [69] further diversify the transnationally-mobile, highly skilled groups from both the global North and the global South [70-73].

'Skilled transients' is one label for this very varied group of temporary contractual workers [64], in which the temporariness of such overseas working sojourns occurs at young and youthful ages, contracts are of short duration - three or four years - and returns home are the expected termination, unless renewal lengthens the working contract for another period. One group comprises the middle-class technical fraction of the transnational capitalist class that Sklair [74] conceives as 'global professionals', who are temporarily employed with highly remunerative contracts in 'far-flung' global workplaces where specialist work is needed (but which is in short supply, or is technically beyond the skills of the local labour force).

"Middling" forms of transnationalism, is how these middle-class cohorts have been referred to, so as to express their character and their trans-local situations in which: "[in] terms of the societies they come from and those they are traveling to, they are very much in the middle," ([68] p. 229). And, Rogers [75] also champions a 'middling transnationalism' as a productive broadening of the field. Supporting the wider and broader lenses that Conradson and Latham [68] and Yeoh et al. [34] advocate [see the section that follows], Rogers [75] incorporates "those in the middle" in the transnationalism domain-practices, experiences and 'projects' he sees occurring in Europe, consisting of working holidaymakers, 'gapyear' student sojourners, and overseas contractteachers of foreign languages.

\section{Transnational Cultures, Spaces and Sites}

(5) Another approach built on, and extended, GlickSchiller et al. 's $[41,47,48]$, cultural lens, but viewed transnationalism as a complex but fundamentally closed system of cross-border relationships which were so inclusive that they virtually erased geographical and social distinctions between origins and destinations. Mountz and Wright's [76] ethnographic exploration of the transnational migrant community of San Agustín, Oaxaca and 
Poughkeepsie, New York and their designation of a single transnational 'locale' to represent the alterations in the conceptualization and utilization of space and time of those involved, is an exemplar of this conceptualization.

Returning to the conceptual debate, after some reworking of the original framework, Levitt and Glick Schiller [8] championed the transnational social field in which they were at pains to distinguish "between ways of being and ways of belonging" (p. 1002). They were also adamant that the boundaries of social life require redefinition and rethinking, such that "[s]imultaneity, or living lives that incorporate daily activities, routines, and institutions located both in a destination country and transnationally, is a possibility that needs to be theorized and explored" ([8] p. 1003). Bailey et al. [77] also followed this theme, through explorations of Salvadoran experiences in a transnational social field that links the towns of El Salvador and northern New Jersey, where these migrants' 'temporary permanent status' as refugees permeates most aspects of their daily lives in the U.S., and their transnational existence "between two worlds".

Such thoughtful conceptual re-positioning concerning transnationalism's distinctions from international migration was helpful $[8,56]$, but not everyone was convinced, charging, among other criticisms, that "the literature's conceptualization of transnation-alism is largely reification" ([20] p. 1182) (the authors' emphasis). Waldinger and Fitzgerald [20] found fault with the initiating anthropologists' focus on particular peoples and places, because this largely ignored transnational connections which extend beyond the loyalties and affinities that connect them to specific places of origin or to ethnic or national groups. On the contrary, Waldinger and Fitzgerald [20] charged that the transnational context serves to limit and constrain migrant action and activism:

\footnotetext{
'[s]tates and the politics conducted within their borders fundamentally shape the options for migrant and ethnic trans-state social action... while international migrants and their descendants recurrently engage in concerted action across state boundaries, the use, form and mobilization of the connections linking here and there are contingent outcomes subject to multiple political constraints' ([20] p. 1178-1179).
}

Geographers, collectively grouped here as a seventh perspective in this discourse, also weighed in with their criticism that much of the earlier work underestimated the significance of space in the constitution of various forms of transnationalism [3, $29,78]$. Ley [78] in his critical examination of the shortcomings of a perspective that privileges "a supra-human transnational space of flows," reminds us that human agency, the 'experience on the street', and each destination/host city's particular and special geographic locale, are not at all dominated and determined primarily by global geo-economics.
Rather, transnational actors are both local and cosmopolitan, nationalist and post-nationalist, and the local and the global are inseparably intertwined because "identity, expressed in sentiment and action, is itself extended, stretched across space and distributed among two or several widely separated sites" (p. 156). Ley and Waters [29] further argue that even in the purest case of transnationalism, as reflected in the 'astronaut households' of Hong KongChinese businessmen, where the prerequisites of a supra-human space of flows, or fully-integrated simultaneous social field are most fully met, spatial stickiness remains. For example, the spatial separation of the transnational family brings its cultural and social tensions to the fore, challenges and erodes traditional patriarchy and redefines identity within families, between generations, and in the wider kinnetworks of individuals involved.

Jackson et al. [3] also stress the importance of the geographical imperative, but particularly, present their case for heterogeneity in transnational formations. They argue that "space is constitutive of transnationality in all its different forms" (p. 1) and that the different transnational formations that are emerging in the U.S., Canada, the Asia Pacific rim and Europe, are themselves distinguished by their different geographies, their particular spatialities. An expansive notion of transnational space is advanced that is at once complex, multi-dimensional and multiply inhabited [79], with increasing numbers of people participating in the resultant 'spaces of transnationality', irrespective of their particular ethnic identities, migrant histories, mobility and immobility behaviours, or their embeddedness in transnational family or kin-based networks, and communal institutions. In short, people from various backgrounds interact in transnational space bringing with them a whole range of social, economic and cultural investments and acting from various positionalities as producers, exchangers and consumers. Jackson et al. [3], therefore, adopt a much wider stance than the earlier sociological conceptualizations (such as Portes et al. [15]), and seek to extend the study of transnationality and transnational connections to "encompass a more multidimensional, materially heterogeneous social field, characterized by multiple inhabitations and disjunctions" ([3] p. 15).

Further widening of the notions of transnationality and transnationalism is to be expected, with research going beyond restrictive definitions of the likes of Portes et al. [15]. In this way, the search for variety, difference, margins and edges in contexts, spaces and places will represent a welcome recognition of the importance of spatial differentiation in the global-tolocal contexts, and will afford an acknowledgement that globalization and transnationalism have not heralded the 'end of geography' [80]. Promoting a wider agenda of this sort, Yeoh et al. [34] concentrate on the 'edges' of transnationalism as sites of analysis which 'unmoor' the contexts of transnational social spaces and examine their recoded conceptual 
framework in terms of "the actual living spheres and projects of transmigrants which span a number of residential and geographical spaces" [16]. Hence, following Faist [81] the resultant 'transnational morphologies' were always going to be "dynamic social processes, not static notions of ties and positions" (p. 40). Conceptualizing 'different communities of affinity' which come together in transnational space, Yeoh et al. [34] recognize a widening and redefining of transnationalism and transnational circuits by relations of class, gender, ethnicity, nationality, generation, occupational type or skill level, and by 'project'; of which electronic communication networks may be the facilitator, as much as the ties and linkages that are formed across borders. Furthermore, such transnational circuits or projects may be formed in contradistinction to one another, or as mixed hybrids, so that the transnational spaces have 'centers', 'margins', 'mixes' and 'edges' where the politics and social processes play out differently. In such contexts, the resultant transnational networks evolve and consolidate conditionally and transnational identities are fluid and flexible, even as they are grounded in particular places at particular times [34]).

(9) Also weighing in with another re-conceptualization, Faist [6] differentiated three forms of transnational social spaces according to their social-capital linkages: (a) transnational family and kinship groups, (b) transnational circuits of goods, people and information, and (c) transnational communities. Unfortunately, in these otherwise insightful characterizations, the traversing of borders of sending and receiving nation-states is the only activity that characterizes the transnational geography of this mobility system. The receiving society's institutional barriers, immigration policies and practices, entry mechanisms and the like, are influential conditioning factors, to be sure. But this conceptualization of transnational social spaces does not effectively recognize the importance of the socio-cultural milieus of the actual locales where migrants come from and where they go, and the attachments they feel to their 'home-place' and 'homes away from home' places (and people, family, community), that make up their network. It does, importantly, recognize the fundamental role transnational families play in the accumulation and sharing of social capital among members and across boundaries, but there is more to transnational family influences than Faist [6] acknowledges in his re-conceptualization.

Levitt [82] gets closer to the point in her assessment of the transnational social spaces of secondgeneration individuals who enact selective transnational behaviors. The ever-evolving nexus of family relations and members' life-course transitions is often assumed in this particular examination but never spelled out thoroughly. Levitt [82] highlights three combinations of influential factors on the second-generation of America's newest immigrants: (i) high levels of institutional completeness and the persistence of strong, multigenerational social networks that give migrants extensive opportunities for transnational participation and choices about where they want to locate themselves and how they behave; (ii) life-course effects that produce different levels of intensity of transnational practices at different stages of the life-course (including constant, frequent transnational involvements, periodic but sustained transnational practices and fervent transnational activities (even activism)), and (iii) the class and racial characteristics of transnational migrant members of enclave communities "away from home" ([82] p. 125). And, in her most recent assessment of transnational influences on the lives of an extremely diverse set of second-generation immigrant children in Boston, Levitt [83] does allude to the point that homeland influences cannot be entirely discounted as important to their societal incorporation - though we go considerably farther than her in this respect.

In any case, whether the behaviors of first- or secondgeneration transnational migrants are different or similar is not an issue in these conceptualizations, because the second-generation immigrants under the lens of Levitt et al. [9, 13, 82-84] are predominantly children or those just beginning young adulthood while resident in the United States. They are, therefore, still in the early, insecure and dependent stages of their life-course, that are scarcely conducive to adventurous travel designs, to overseas sorties into the unknown, separation from their school friends, family and familiar local environment- neighborhood, school, home, their own room; to wit 'security' rules.

\section{TRANSNATIONALISM AND THE SECOND- GENERATION}

While the definitional flux surrounding the exact concept of transnationalism has not yet resolved itself, there is a growing academic consensus that a broadly transnational approach allows a more rounded overview of international migration and immigrant communities than the assimilationist perspectives previously embraced by researchers. This is nowhere more evident than in research regarding the 'next-generations', particularly the secondgeneration in situ, long regarded purely as a test-bed for successful or failed assimilation, where transnational approaches have unearthed stronger and more complicated relationships with the ancestral homeland, country of origin, immigrant identities, and family and kinship groups than had been originally envisaged.

\section{Assimilation and the Emerging Second-Generation}

Earlier studies on assimilation and the incorporation of the second-generation into society had neglected to take into consideration that some children of first-generation migrants have strong links and ties to their parents' ancestral homeland [13]. The last decade or so has seen a growing academic interest in second-generation migrants, particularly in the US, with the emergence of a number of studies on the children of immigrants who were born in the United States, particularly US-born children of Mexican and Asian firstgeneration immigrants and those who came to the country when they were young and were raised and educated in the 
United States ('1.5-generation') [13, 85]. However, the bulk of the research over the past fifteen years on the secondgeneration in the US has been approached from a framework of assimilation, adaptation and integration [85-87]. Following Piore's [88] notions of 'Birds of Passage', and many other American social scientists and urban ecologists of like mind, it has commonly been assumed that immigrants would eventually assimilate into their host country. Therefore, it was thought only logical that the children of first-generation immigrants would also assimilate into their birth country. Early American research on the secondgeneration proceeded from the assumption that the children of immigrants would assimilate, or be characterised by stronger attachments to their family's adopted homeland than to their parents' ancestral homeland and would thus not demonstrate transnational practices.

Without explicitly recognising the U.S. exceptionalism in their empirical contexts, or at least remaining conceptually cautious so as not to commit an ecological fallacy in their generalizations, much of the second-generation migration research literature has been dominated by US scholars and has focused on second-generation immigrants' experiences in the US. In particular, the theoretical models used to explain the position of the second-generation have been generalised without taking note of the unique nature of the racism and racial chasms that have long divided and segregated American society [13, 89-92]. Gans [92] put forward the concept of 'second-generation decline', arguing that second-generation immigrants have poor economic opportunities, are restricted in their access to good schools, education and jobs, and therefore experience downward mobility relative to that of their parents. Portes and Zhou [93] suggested a theory of 'segmented assimilation'. This 'segmented assimilation' model describes the possible outcomes of different second-generation groups and their adaptation to American society. Portes and Zhou [93] argue that the level of incorporation for the first-generation results in different types of opportunities, social networks, cultural and social capital for the second-generation. For Portes and Zhou [93] the second-generation groups who have the best economic opportunities for upward mobility are the groups who resist acculturation. The groups who do not resist acculturation have a strong possibility of experiencing downward assimilation and joining the urban underclass.

\section{The European Second-Generation}

Recent studies of the European second-generation offer an alternative view to the established US-based research and theories on the second-generation. Firstly, as Thomson and Crul [87] argue, the American-centric debate on the integration of the second-generation has largely concentrated on comparing different ethnic groups in the same exceptional national context - the US. As Thomson and Crul [87] point out, it is only recently that North American research has started to look at the importance of the 'national context' in which immigrants and their children live and work, whereas in Europe, 'national context' has received more attention over the years. For them, this European contribution of 'national context' is an important factor in the integration of the second-generation and has consequently contributed to the international theoretical debate on integration. Secondgeneration European groups are also ethnically very different to those in the US, and differ significantly in terms of their migration and settlement patterns - in Europe the parents of the largest second-generation groups tend to have migrated from ex-colonies or were recruited as labour migrants [87].

It is also important to stress that the American idea of 'downward assimilation' and 'segmented assimilation' are not necessarily applicable to the European and UK secondgeneration populations. Studies on educational performance among different ethnic groups show that Indian children of immigrants have consistently out-performed British white groups at school $[94,95]$. However, this appears not to the case for Afro-Caribbean and South Asian pupils in the UK who do not perform as well as their British White and British Chinese and Indian counterparts: "African-Caribbean, Pakistani and Bangladeshi pupils are markedly less likely to attain five higher grade GCSEs than their White and Indian peers nationally" ([95] p. 12). Many explanations for this relatively poor performance have been put forward, one being that teachers have lower expectations of AfroCaribbean boys' academic abilities. Other explanations have been put forward to explain these disappointing performances, such as a lack of black role models in schools, a lack of culturally-relevant subjects in the school curriculum, a lack of parental involvement and "the fact that so many black boys are brought up in fatherless families, which deprives them of other masculine role models", and a suggested "anti-education culture" in the black Caribbean community ${ }^{1}$.

One overriding theme is institutional racism and racist school practices in the UK [96-98]. For Sewell [97] black Caribbean boys experience pressure from their peers to adopt the norms of an 'urban' or 'street' sub-culture, thereby placing more prestige on disruptive behaviour towards teachers than on academic achievement. Exclusion and expulsion estimates also show that black Caribbean and mixed ethnic groups are the only groups over-represented relative to white British pupils among those excluded from school [99]. What is clear is that an American theory of 'downward assimilation' is dependent on a set of American economic and social structural features that do not necessarily feature, extend or cross over into the UK and Europe.

Recently, some scholars have begun to go beyond assimilationist arguments and to consider transnationalism and the second-generation's experiences. While some scholars maintain that transnationalism is a temporary phenomenon that will disappear as the second- and thirdgenerations assimilate into the home country [4], others suggest that transnationalism will carry over and continue for several generations $[45,100]$. At this point, it should be noted that much of the earlier research on the secondgeneration from a transnational perspective was influenced by Portes' et al's [15] practice-based definition, and hence a strong emphasis was placed on 'regular and sustained' patterns of transnationalism and return migration was viewed as the key signifier of transnational activity. A definition of transnationalism taking its cue from Faist's [6] more relational perspective, as elaborated in greater detail by Levitt [7], offers much greater scope for an examination of

\footnotetext{
${ }^{1}$ Sewell T. The Race Challenge: The Sunday Times, 2002 December 15.
} 
transnationalism in the second-generation. Research from this perspective in particular supports the idea that transnationalism is 'alive and well' among secondgeneration groups, and in more than a few selective cases, has resulted in a cohort of second-generation individuals migrating to their parent(s) country of origin [101-110]. However, on a cautionary note, whilst some among the second-generation undertake many transnational practices, others exhibit very few transnational traits, habits or sentiments.

\section{TRANSNATIONALISM, THE LIFE-COURSE AND THE CARIBBEAN COMMUNITY IN THE UK}

As recent research has shown, transnational practices are 'alive and well' among some members of the secondgeneration, 'return migration' being one clear example of transnational practices in operation. However, the question remains, why are some individuals more transnational than others? It is clear that there are a number of factors that lead to, and influence, the transnational activities of members of the second-generation, such as race, gender, class and lifecourse. The socio-economic status of parents and their transnational backgrounds and familial links to the ancestral homeland, the pressure on children to engage in transnational practices and the importance attached to ancestral homeland and keeping in touch with extended family 'kith and kin'. The life-course experiences of the second-generation in the wider host society will also have a considerable bearing on the second-generation's embrace of transnational identities and transnational praxis $[111]$. This is clearly demonstrated by the Caribbean community in the UK.

\section{The Caribbean Community in the UK - A Brief History of Migration and Settlement}

The UK Caribbean community is far from being a homogeneous entity; it is in fact, diverse, including migrants and their descendents originating from a number of Caribbean islands (Barbados, Grenada, Jamaica, St Lucia and Trinidad and Tobago among them). Migration from the Caribbean to Britain from the 1940s onwards was primarily for socio-economic reasons. Caribbean migrants were attracted by employment in factories and service sector industries and to government-sponsored recruitment schemes [112]. One of the earliest countries to be affected by migration was Jamaica. By 1948, 547 Jamaicans had emigrated to the UK [113]. Migration from the Caribbean to the UK continued during the 1950 s due to the post-war labour shortage which encouraged immigration from the Caribbean. However, by 1962, migration from the Caribbean to the UK had significantly dropped due to the Commonwealth Immigration legislation, which came into effect in that year [114]. Indeed, the number of people actually born in the Caribbean and living in Great Britain peaked in the mid 1960s, and by 1973 mass migration from the Caribbean to Britain was effectively over [112].

By 1951, there were 17, 218 Caribbean born people in Britain, the majority of whom were Jamaican. By 1961, the Caribbean born population stood at 173,659 and by 1971 it had risen to 304,070 , with a total Caribbean population figure of 545,744. At the start of the 1990s, the Caribbean born population was 264,591, indicating a decline in the
Caribbean born population which was a result of mortality and to a certain degree return migration to the Caribbean [112]. However, when we include the UK born children of these Caribbean immigrants, the Caribbean population of Great Britain stood at 678,365 in $1991-1.2$ per cent of the total population [115]. The structure of the Caribbean population in 1991 clearly showed three generations - the original post-war immigrants, who had reached late middle age in 1991, their children, mainly born in the 1960s, and grandchildren. The second-generation was by far the largest; with the largest single age cohort being people aged 35 to 49 . It is important to note that the 1991 census only covered around 98 per cent of the population, resulting in an underestimate of 1.2 million people. Therefore, it has been estimated that the Caribbean population is nearly 4 per cent larger than the census figure [115]. In 2001, 1.0 per cent $(565,876)$ of the total UK population were Black Caribbean, making up 12.2 per cent of the minority ethnic population. Black Caribbeans form more than 10 per cent of the population of the London Boroughs of Lewisham, Lambeth, Brent and Hackney [116].

As early as 1961, clear geographical patterns of Caribbean settlement had emerged and have largely endured over the years. Demand for labour in Britain during the Second World War 1939-1945, had resulted in several thousand West Indians volunteering for the British armed services, and many were recruited to work in the Merseyside munitions factories [117]. In the subsequent post-war period, other gaps emerged in certain industries in certain areas. The upward mobility of the white population had left gaps in certain jobs that needed to be filled by a 'replacement population'. British Rail, British Transport and the National Health Service recruited labour directly from Barbados. Indeed, the Government of Barbados in 1955 set up a sponsorship scheme under which the British Transport Commission, the London Transport Executive, the British Hotels and Restaurants Association, and the Regional Hospital Boards received workers. One striking feature of this 'replacement population' is its impact on the geographical distribution in the UK of the Caribbean community. London, the South-East, East and West Midlands, the West Riding of Yorkshire and later the NorthWest had high levels of Caribbean immigration [112, 117]. Caribbean migrants tended to locate themselves in urban areas, with over 55 per cent of the Caribbean population living in Greater London and 13 per cent in the West Midlands. By 1991, nearly two-thirds of all Caribbeans in Britain lived in South East England. Caribbeans made up 5.6 per cent of the population of London. Outside London, the next largest Caribbean population was in Birmingham $(56,000)$ [115].

\section{Return Migration}

Research on the Caribbean community from the 1960s onwards has been focused on the first- and older Caribbean generation of emigrants to the UK, namely, the "Windrush generation' - exploring their position in the UK, the sending of remittances to the Caribbean and in the later stages, those who have decided to 'return' to the Caribbean. Research since the late 1970 s has documented return migration to the Caribbean with much attention on returning nationals of retirement age, focusing on their social, economic and 
behavioural adjustments upon arrival [118-120]. Earlier research had highlighted the trend for first-generation Caribbean migrants to hold on to the belief that one day they would return 'home' and live in the house they had build with remittances they had sent back over the years. According to John [121] this long held belief among the first-generation became a "useful psychological game" as many first-generation immigrants knew and admitted to themselves that they would never go back. John [121] also felt that this long cherished notion of returning home was unlikely to be held by the second-generation who he believed were "here to stay". This view was also shared by Midgett [122] who believed that generational differences between the first- and second-generations made it highly unlikely that the second-generation would ever consider returning to the Caribbean as "culturally they have very little to distinguish them from any other black children in London. They cannot speak patois, the language of their parents; they have no recollection of an island or village home; and they even reject the cuisine of their parents in favour of fish and chips" (p. 76).

Although earlier research on the black Caribbean community in the 1970 s tended to view return to the Caribbean as a first-generation phenomenon, recent research has shown that second-generation return migration is a facet of life for a small cohort of individuals. Research during the early 2000 s identified a relatively new migration stream to the Caribbean region which until quite recently had remained largely unseen and under-studied - the movement of comparatively young second-generation returning nationals to the Caribbean.

In the late 1990s, Potter [101-105] on research trips to the eastern Caribbean met a growing number of secondgeneration returning nationals. This young group of people who are second-and third-generation Caribbeans, born in the United Kingdom, United States or Canada or elsewhere, of first-generation Caribbean immigrants had, for a variety of reasons, decided to 'return' to the countries of their parents. As a result of this discovery, a total of forty young returnees were interviewed in Barbados and St Lucia from 1999 to 2000 to examine this relatively new group of migrants' experiences. This research concentrated on the socioeconomic and demographic characteristics of these young returnees, their pattern of visits to the island prior to migration and the reasons for their move, the adjustments made by the returnees and the essentially 'hybrid' and 'inbetween' positionalities of these transnational migrants [101, $102]$.

Post-colonial theories of identity have argued the essential 'inbetweeness' and hybridity of migrant identities [123]. However, post-colonial writings have tended to overlook the return experiences of migrants to their postcolonial origins, and how an increasing proportion of economic relations, and the existence of transnational and transcontinental labour market flows have contributed to the emergence of new hybrid identities [124]. Consequently, they have failed to recognise the importance of transnational connections, crossings and tensions between Africa, the Caribbean, America and Britain [125]. As a result, little is known about return adjustment, negotiation patterns and hybrid identities connected with post-colonial return.
Consequently, a number of working hypotheses concerning the adaptation experiences of these young returnees were developed, which in turn became the focus for a major study of second-generation young returnees to the region, with work starting in 2002, funded by the Leverhulme Trust [104, $105,126]$.

It is clear that 'return' migration is a significant indicator of transnational practices among a section of the Caribbean community in the UK. As the world effectively becomes "smaller" and technology and communication have improved, maintaining links with family members in other countries has become easier not only for the first-generation but also for the second- and third-generations. It is fair to say that for second-generation people to understand their life and identity there has to be some understanding and awareness of the ancestral homeland. So, whilst there have been a number of explanations put forward concerning the motivations and reasons behind this 'return' among the 'next generations', including Anwar's [127] 'myth of return' being passed on from parents to their offspring and of course regular return visits to the ancestral homeland from a young age, regular and sustained contact with remaining family members via email, the internet and phone can also be singled out as motivators. However, in the case of second-generation return migration to the ancestral homeland, the life-course stage an individual has reached is of equal importance in determining motivation to travel.

\section{Transnationalism and the Life-Course in the Caribbean Community}

Levitt [82] recognises the importance of life-course stages in determining and influencing transnational connections, strategies and identities and acknowledges that different levels of intensity of transnational practices will accompany succeeding stages. We can agree that, among Caribbean transnational communities and in Caribbean transnational families $[5,106,128-133]$, transnational experience deepens and becomes more resilient and influential with age, experience and network strengthening. We can further propose that the accumulated stocks of transnational connections that many Caribbean migrants (now of several generations) rely upon, are likely to become more central to transnational family strategy-formation. They will reinforce and strengthen intra-generational transfers of transnational social, economic and cultural capital, and generally encourage risk-averse behavior and action with reference to transnational ties, obligations and rewards.

In addition, life-course stage effects become intertwined, or merged, not only with immediate family formation stages, but the life-course and family formation (and dissolution) stages of first-generation grandparents, first-generation parents, and those among their influential 'lateral family' siblings, aunties and uncles [128]. These extended family connections and relations not only serve as social support systems to members of transnational family networks in the multi-local diaspora and at home. They also influence and affect the transnational and intra-generational bonds, linkages and ties of migrants and members of transnational family networks to each other. Within such family networks migrants develop intra-generational bonds with parents, or 
with one particular parent, grandparent, 'tantie', uncle, 'godfather' or an elderly sponsor or guardian, and rely upon such bonds to support and influence their cross-border mobility. They are also likely to build relationships with siblings, selectively drop ties and re-engage with long-lost, distant kin and family members, if pragmatic considerations demand it [134-136].

More generally, these extended and 'lateral' Caribbean transnational families occur in a myriad of unconventional forms $[128,130,137-140]$. In part, they originate in the unconventional structure(s) of the Caribbean stem family that has often been criticized as 'deviant' or 'dysfunctional' because it was 'matrifocal' rather than 'patriarchal', which seemingly does not conform to the notions of the modernized, 'nuclear family' of Britain and the British Empire ([141] Potter et al. chapter 5 [142]), or of the Western, 'North Americanised' world [143] (see Chamberlain [129] for a lengthier argument about Caribbean family 'closeness and love' in the diaspora). In part, the transnational experiences and resultant practices of Caribbean families have also contributed to the dynamic and changing relationships within such extended and lateral families, which have sometimes confounded conventional wisdoms about the inevitable disruptive influences and problems of long-distance relationships, separation of siblings, parental separations, and children left behind [144, 145]. Transnational family formation can also occur as a consequence of bi-national marriages at home and abroad, such that dual identity formation, dual nationality and transnationalism become pragmatic, life-course arrangements for parents and the children of such families [106, 146]. Sometimes, however, migration, flight, separation and long-distance absences have contributed to problematic breakdowns and family stress. The general 'story' is therefore multifaceted and exists constantly under tensions brought about by the changes occurring within Caribbean transnational networks, transnational families, transnational multi-local social spaces, and their inter-related Afro-Caribbean, Indo-Caribbean, British-Caribbean, Canadian-Caribbean, American-Caribbean and farther-flung global diasporic partners and kith and kin.

\section{Transnationalism and the Second-Generation Caribbean Community In Situ}

The work of Goulbourne [147], Goulbourne and Chamberlain [132] and Reynolds [148] has been particularly fruitful in supplying new perspectives concerning the second-generation British-Caribbean community in situ in the UK. Recent research on second- and third-generation young people of Caribbean descent in Britain is closely related to transnationalism and its impact on the lives of these individuals. Reynolds [148] suggests that second- and third-generation young people of Caribbean descent in Britain participate in transnational family and kinship events and celebrations, thus encouraging them to be part of a globally dispersed family. This participation influences their ethnic identity formation and re-affirms a transnational Caribbean ethnic identity. She argues that over the years, policy analyses addressing minority ethnic groups in the UK have used racial stereotypes to try to develop an understanding of family relationships in the black community. One result of this ethnic stereotype is an assumption that Caribbean families have 'weak' social capital: low levels of participation in civil activities, low levels of voting, poor educational achievement and high levels of single parent households and high levels of youth unemployment and crime.

This is seen as too simplified an argument for Reynolds [148], who suggests that by ignoring cultural factors and structural constraints you dismiss the idea that different ethnic groups develop, sustain and access social capital in diverse ways. Her research looked at thirty second- and third-generation Caribbean young people (aged between 16 and 30), primarily in London, but also in Birmingham, Manchester and Nottingham and fifty kinship/family members in Britain and the Caribbean (Barbados, Guyana and Jamaica). Reynolds ([148] p. 1093) argues that Caribbean families do have 'strong' social capital, as they demonstrate "strong 'bonding' social capital in racial-ethnic specific community events" and are much more likely to participate in these areas (e.g. Saturday schools, black church groups and Caribbean welfare based organisations). For Reynolds [148], this strong 'bonding' social capital is a useful starting point in developing and understanding young peoples' lives and their family social networks. This 'bonding' social capital is not confined to their local area or nation-state; on the contrary, 'bonding' social capital is understood within a transnational context which allows young Caribbean people to access, and link into, transnational social resources and family activities. By using this social capital to establish cross-ethnic networks, relationships and bonding social capital within the transnational family, young Caribbean people reaffirm and develop a Caribbean cultural identity [149]. Within a society where young Caribbean people may feel excluded and marginalised, Reynolds [148] believes that by participating in these transnational networks, young Caribbean people feel a sense of belonging and collective membership. As a result, some young Caribbean people carve out multiple ethnic identities.

Whilst Reynolds [148] argues quite strongly that secondgeneration young Caribbean people have strong transnational links, which results in them developing a Caribbean cultural identity, and do belong to a Caribbean transnational community, there are others who suggest that there are limits to Caribbean transnationalism among first- and secondgeneration Caribbean groups in Britain. Layton-Henry [150] suggests that transnationalism is not being sustained among second- and third-generation British born Caribbeans and that even among the first-generation, transnationalism is not strong or sustained.

Layton-Henry's [150] research looked at a Birmingham sample of thirty-five participants all aged between 16-50 years. Twelve were born in the Caribbean, mainly in Jamaica, whilst the remaining twenty-three participants were born in Britain. He also interviewed a further twenty Caribbean men in group discussions. He uses Portes et al's [15] definition of a transnational community as involving a large part of the immigrant community in sustained contact and activity between the two countries over a period of time for the first- and second-generations to justify his explanation that "African-Caribbean people in Birmingham do not belong to a transnational community" ([150] p. 19). 
He describes migration from the Caribbean to Britain from the 1940s onwards as almost "internal rather than international", as "African-Caribbeans from the British West Indies were British subjects with a strong identification with Britain". These Caribbeans arriving in Britain had citizenship rights on their arrival; thereby they were afforded formal and legal status. However, this British citizenship did not necessarily mean a warm welcome from the indigenous population; instead these Caribbean migrants often met with "suspicion, fear, discrimination and racism" ([150] p. 7). Layton-Henry argues that as result of this discrimination, Caribbean migrants could have identified more strongly with the Caribbean by retaining dual-nationality and engaging in more transnational activities such as leading dual lives, living in two cultures and maintaining a living through regular contact across national borders. Layton-Henry [150] argues that they did not maintain 'physical and actual' links but rather 'emotional and sentimental' links with the Caribbean for a number of reasons. He proposes that the distance between Britain and the Caribbean and the cost of travel and the fact that the Caribbean community in Britain is not a wealthy one meant that transnational activities and links were hard to sustain and maintain. He also suggests that most British-born Caribbeans marry British partners, unlike other migrant communities who seek partners from their countries of origin and a result of this growth of exogenous partnerships is the clear social integration of Caribbean people in the UK.

The work to date on the Caribbean community in situ would suggest that there are conflicting opinions on the existence of transnationalism among members of the community. Whilst Layton-Henry [150] adopts Portes et al's [15] very clear cut definition of transnationalism, suggesting that transnationalism among the wider community is weak, 'return migration' to the Caribbean among members of the first and now second-generation members would suggest the opposite, as would Chamberlain's [129, 144] recognition of the transnational ties among Caribbean families, and the accumulated stocks of social, cultural and human capital identified by Reynolds [148]. This would suggest that the idea that transnationalism is weak, hard to sustain and even missing among members of the Caribbean community in the UK needs revisiting, rethinking and readdressing.

\section{CONCLUSIONS}

Transnationalism still continues to divide, shape and inform debate in respect of international migration, new immigrant identities and communities and migrants' links to their countries of origin. From the early definitions by Glick Schiller et al. [41, 48] based on US-destined immigrants, to alternative conceptualisations from Vertovc [17] and Portes, Guarinzo and Landolt [15] to Smith and Guarnizo's [57] "transnationalism urbanism", whilst not forgetting the geographers' contribution on the significance of space and transnationalism $[3,29,78]$, we can concur that there is indeed, much 'conceptual muddling' [17].

Whilst it is not immune from critics and doubters [4, 20], transnationalism still has an important role to play in our understanding of contemporary migration and immigrant communities in post-colonial societies. Having widened its empirical base from one that was originally dominated by
US-based discourse to one that engages with Europe and Asia and beyond, there is no doubt that the concept's relevance is now more than ever tied up in an interconnected global system and one in which countries can no longer be defined as territorially 'closed systems' surrounded by impenetrable, 'secure' national borders. Accompanying this is the recognition of the role transnationalism can play in influencing and informing host and source government policies, both nationally and globally. This role should not be overlooked or underestimated when applied to international emigration/immigration, circulation and return migration, among other global mobility and immobility options.

Throughout this debate on the role and relevance of transnationalism and its position alongside paradigms of immigration, assimilation, and migration, one thing remains clear; immigrants and their children can and do have multiple identities. Transnationalism as a paradigm goes a long way in furthering our understanding of the 1.5-, secondand third-generation individuals and their position and experiences in the globalised but no less heterogeneous world in which we live today. In the last decade, research has shown that transnational practices occur among the secondand third-generations. Although, not all second-generation or even third-generation people will have multiple identities or identify with their parents' and grandparents' country of origin, there are a significant number who are transnational, and who at the very least engage in some transnational activity, which calls into question Kivisto's [4] argument that transnationalism is a first-generation phenomenon that disappears with the second- and third-generations.

As Reynold's [148]) research on the British-born Caribbean second- and third-generation community has shown, transnational practices and transnationalism remain strong for some sections of the second-generation Caribbean community. Potter's [101, 102] research on secondgeneration 'return' migration to the Caribbean again demonstrates that for a cohort of people, ties to the ancestral homeland are alive and strong. Potter and Conway [151] indicate that in some instances these young and professional British-born Caribbeans, American Afro-Caribbeans and Canadian-Caribbean second-generation returned migrants who are equipped with social and human capita are "making a difference back home" in the island homes of their parents. Their transnationality has the potential to prompt and sustain change in "social institutions, business circles, the expanding private sphere and the modernizing public service sectors" in the homeland of their parents' [151]. Research by Christou [108] on second-generation Greek-American return and Wessendorf's [110] research on second-generation SwissItalian return also indicates transnational practices among the second-generation. Ongoing research on these so-called 'next generations' is needed to continue to add to the existing empirical base.

With the Caribbean case in mind, it is evident that transnationalism has a role to play in widening our understanding of this community in the UK today. Notwithstanding the considerable body of literature on the first-generation Caribbean community and in recent times, research on the second-generation Caribbean community, return migration and Caribbean social capital in the UK, it is 
evident that there is scope for more work on the Caribbean 1.5-, second- and third-generation communities in situ. Research examining the 1.5 generation and the British-born Caribbean second- and third-generation 'life-worlds' in the context of Caribbean transnational experiences and practices in situ, their inter-generational transfers of transnational practices, family migration patterns, life-course transitions, and their views of the ancestral homeland and intentions to return (or not), are certain to enrich the growing body of literature on Caribbean transnationalism's deepening and widening influences.

\section{ACKNOWLEDGMENTS}

The work in this paper has been supported by a University of Reading Graduate School for the Social Sciences (GSSS) Studentship.

\section{REFERENCES}

[1] Foner N. West Indian identity in the diaspora: comparative and historical perspectives. Lat Am Perspect 1998; 25(3): 173-88.

[2] Foner N. Islands in the city: West Indian migration to New York. Berkeley, Los Angeles and London: University of California Press 2001.

[3] Jackson P, Crang P, Dwyer C. The spaces of transnationality. In: Jackson P, Crang P, Dwyer C, Eds. Transnational Spaces, London and New York: Routledge 2004: pp. 1-23.

[4] Kivisto P. Theorizing transnational immigration: a critical review of current efforts. Ethnic Racial Stud 2001; 24(4): 549-77.

[5] Conway D. Caribbean transnational migration behaviour: reconceptualising its "strategic flexibility". Popul Space Place 2007; 13: 415-31.

[6] Faist T. The volume and dynamics of international migration and transnational social spaces. Oxford: Clarendon 2000.

[7] Levitt P. Transnational migration: conceptual and policy challenges. In: Palme J, Tamas K, Eds. Globalizing migration regimes, Aldershot, UK and Burlington, VT: Ashgate 2006; pp. 23-36.

[8] Levitt P, Glick Schiller N. Conceptualizing simultaneity: a transnational social field perspective of society. Int Migr Rev 2004; 38(3): 1002-39.

[9] Levitt P, Jaworsky BN. Transnational migration studies: past development and future trends. Annu Rev Sociol 2007; 33: 129-56.

[10] Ley D, Kobayashi A. Back to Hong Kong: return migration or transnational sojourn? Global Netw 2005; 5(2): 111-27.

[11] Bailey AJ. Turning transnational: notes on the theorization of international migration. Int J Popul Geogr 2001; 7: 413-28.

[12] Goulbourne H. The socio-political context of Caribbean families in the Atlantic World. In: Goulbourne H, Chamberlain M, Eds. Caribbean families in Britain and the Trans-Atlantic world, London: Macmillan Education Ltd 2001; pp. 12-31.

[13] Levitt P, Waters MC. Introduction. In: Levitt P, Waters MC, Eds. The changing face of home. The transnational lives of the second generation, New York: Russell Sage Foundation 2002; pp. 1-32.

[14] Portes, A. Transnational communities: their emergence and significance in the contemporary world-system. In: Korzeniewicz RP, Smith WC, Eds. Latin America in the World-Economy, Westport, Connecticut: Praeger 1996; pp. 151-68.

[15] Portes A, Guarnizo LE, Landolt P. The study of transnationalism: pitfalls and promises of an emergent research field. Ethn Racial Stud 1999; 22(2): 217-37.

[16] Pries L, Ed. Migration and transnational social spaces. Aldershot, UK, Ashgate 1999; pp. 162-186.

[17] Vertovec S. Conceiving and researching transnationalism. Ethn Racial Stud 1999; 22(2): 447-62.

[18] Vertovec S. Transnationalism and identity. J Ethn Migr Stud 2001; 27(4): 573-82.

[19] Vertovec S. Migrant transnationalism and modes of transformation. Int Migr Rev 2004; 38(3): 970-1001.

[20] Waldinger R, Fitzgerald D. Transnationalism in question. Am J Sociol 2004; 109(5): 1177-95.

[21] Biao X. Productive outflow of skills: what India and China can learn from each other. Asian Popul Stud 2007; 3(2): 115-33.
[22] Connell J, Conway D. Migration and remittances in island microstates: a comparative perspective on the South Pacific and the Caribbean. Int J Urban Reg Res 2000; 24(1): 52-78.

[23] Conway D, Potter RB. Return migration of the next generations: global perspectives on transnational migration in the twenty-first century. Aldershot, Brookfield, Singapore and Sydney: Ashgate, Forthcoming, Summer 2009.

[24] Hugo G. An Australian Diaspora? Int Migr 2006: 44(1): 105-33.

[25] Iredale R, Gu F, Rozario S, Eds. Return Migration in the Asia Pacific. Cheltenham, UK, Northampton, MA, USA 2003.

[26] King R, Connell J, Eds. Small Worlds, Global Lives: Islands and Migration. London and New York: Pinter 1999.

[27] Yeoh BSA, Willis K. Singapore unlimited: configuring social identity in the regionalization process. Transnational communities programme. Transnational Communities Working Paper Series 1999: WPTC 98-08.

[28] Roger A. An European space for transnationalism. In: Jackson P, Crang P, Dwyer C, Eds. Transnational Spaces, London and New York: Routledge 2004; pp. 164-82.

[29] Ley D, Waters J. Transnational migration and the geographical perspective. In: Jackson P, Crang P, Dwyer C, Eds. Transnational spaces, London and New York: Routledge 2004: pp. 104-21.

[30] Silvey R. Transnational migration and the gender politics of scale: Indonesian domestic workers in Suadi Arabia, 1997-2000. Singapore J Trop Geogr 2004; 25(2): 141-55.

[31] Silvey R. Consuming the transnational family: Indonesian migrant domestic workers to Saudi Arabia. Global Netw 2006; 6(1): 23-40.

[32] Nyberg Sørensen N, Olwig KF. Work and Migration: life and livelihoods in a globalising world. London: Routledge 2002.

[33] Vertovec S, Cohen R, Eds. Migration, diasporas and transnationalism. Cheltenham: Edward Elgar 1999.

[34] Yeoh BSA, Willis KD, Fakhiri SMAK. Introduction: transnationalism and its edges. Ethn Racial Stud 2003; 26(2): 207-17.

[35] Anthias F. Evaluating 'diaspora': beyond ethnicity. Sociology 1998; 32(3): 557-81.

[36] Clifford J. Diasporas. Cult Anthropol 1994; 9(3): 302-38.

[37] Cohen R. Global diasporas: an introduction. Seattle: University of Washington Press 1997.

[38] Vertovec S. Three meanings of 'diaspora', exemplified among South Asian religions. Diaspora 1997; 6(3): 277-99.

[39] UN 2005 Global Commission on International Migration Report. [Cited 2009 February 1]. Available from: http://www.un.org/esa/ population/meetings/fourthcoord2005/P09_GCIM.pdf

[40] Levitt P, Nyberg SN. The transnational turn in migration studies. Global Migration Perspectives 2004; No. 6. Global Commission on International Migration, October: Available from: http://www.gcim. org/en/ir_gmp.html

[41] Glick Schiller N, Basch L, Blanc-Szanton C, Eds. Towards a transnational perspective on migration: race, class, ethnicity, and nationalism. New York: The New York Academy of Sciences 1992; Vol. 645 .

[42] Warner WL. The Social Systems of American Ethnic Groups. New Haven, CT: Yale University Press 1945.

[43] Gordon MM. Assimilation in American Life: the role of race, religion, and national origins. New York: Oxford University Press 1964.

[44] Foner N. 'In a new land': a comparative view of the literature. New York, USA: New York University Press 2005.

[45] Comaroff J, Comaroff JL, Eds. Of revelation and revolution: Christianity, colonialism and consciousness in South Africa. Chicago: University of Chicago Press 1991.

[46] Anderson B. Imagined communities: reflections on the origin and spread of nation. London: Verso 1983.

[47] Glick SN, Basch L, Szanton BC. From immigrant to transmigrant: theorizing transnational migration. Anthropol Q 1995; 68(1): 48-63.

[48] Basch L, Glick-Schiller N, Szanton-Blanc C. Nations unbound: transnational projects, postcolonial predicaments and deterritorialized nation-states. Langhorne, PA: Gordon and Breach 1994.

[49] Foner N. How exceptional is New York?: migration and multiculturalism in the empire city. Ethn Racial Stud 2007; 30(6): 9991023.

[50] Sassen S. The Global City: New York, London, Tokyo, $2^{\text {nd }}$ ed. Princeton, NJ: Princeton University Press 2001.

[51] Foner N. From Ellis Island to JFK: New York's two great waves of immigration. New Haven, CN: Yale University Press 2000.

[52] Keely CB. U.S. immigration: a policy analysis. New York: The Population Council 1979. 
[53] Kessner T. Repatriation in American history. Appendix A, Staff Report of the Select Commission on Immigration and Refugee Policy: Papers on U.S. Immigration History 1981.

[54] Morawska E. Immigrants, transnationalism and ethnicization: a comparison of this great wave and the last. In: Gerstle G, Mollenkopf JH, Eds. E Pluribus Unum?: Contemporary and historical perspectives on immigrant political incorporation, New York: Russell Sage 2001; pp. $175-212$.

[55] Portes A. Introduction: the debates and significance of immigrant transnationalism. Global Netw 2001; 1(3): 181-94.

[56] Levitt P. Transnational migration: taking stock and future directions. Global Netw 2001; 1(3): 195-216.

[57] Smith MP, Guarnizo LE, Eds. Transnationalism from below. New Brunswick, NJ: Transaction Publishers 1998.

[58] Smith MP. Transnational urbanism: Locating globalization. Malden. MA: Blackwell 2001

[59] Smith MP. Transnational urbanism revisited. J Ethn Migr Stud 2005; 31(2): 235-44.

[60] Portes A. Globalization from below: the rise of transnational communities. Oxford, UK, ESRC. Transnational Communities Research Programme 1997; WPTC-98-01.

[61] Giddens A. The constitution of society: outline of the theory of structuration. Berkeley, CA: University of California Press 1984.

[62] Beaverstock JV. Revisiting high-waged labour market demand in the global cities: British professional and managerial workers in New York City. Int J Urban Reg Res 1996; 20: 422-45.

[63] Beaverstock JV. Transnational elite communities in global cities: connectivities, flows and networks. GAWC Research Bulletin 63, Globalization and World Cities Study Group and Network, Loughborough University, UK 2001: Available from: http://www.mi.vt.edu/Research/Files/Transnationalelite.pdf

[64] Findlay AM. Skilled transients: the invisible phenomenon? In: Cohen $\mathrm{R}$, Ed. The Cambridge survey of world migration. Cambridge: Cambridge University Press 1995; pp. 515-22.

[65] Findlay AM, Li FLN, Jowett AJ, Skeldon R. Skilled international migration and the global city: a study of expatriates in Hong Kong. Trans Inst Br Geogr 1996; 21: 49-61.

[66] Castles S. Ethnicity and globalization: from migrant worker to transnational citizen. London: Sage 2000.

[67] Iredale R. The migration of professionals: theories and typologies. Int Migr 2001; 39(5): 8-26.

[68] Conradson D, Latham A. Transnational urbanism: attending to everyday practices and mobilities. J Ethn Racial Stud 2005; 31(2): 22733.

[69] Stalker P. Workers without frontiers: the impact of globalization on international migration. Boulder, CO: Lynne Rienner 2000.

[70] Connell J. The global health care chain: from the pacific to the world. New York: Routledge 2008.

[71] Lovell BL. Policy responses to the international mobility of skilled labour. Geneva: International Labour Office, International Migration Papers 2001; No. 45.

[72] Salt J. International movements of the highly skilled. Paris: Organisation of Economic Co-operation and Development (OECD), Occasional Paper 1997; No. 3.

[73] Vertovec S. Circular migration: the way forward in global policy? Oxford: International Migration Institute, Working Paper 2007; No. 4.

[74] Sklair L. The transnational capitalist class and contemporary architecture in globalizing cities. Int J Urban Reg Res 2005; 29(3): 485500.

[75] Rogers A. Observations on transnational urbanism: broadening and narrowing the field. J Ethn Migr Stud 2005; 31(2): 403-7.

[76] Mountz A, Wright RA. Daily life in the transnational migrant community of San Agustín, Oaxaca and Poughkeepsie, New York. Diaspora 1996; 5(3): 403-28.

[77] Bailey AJ, Wright RA, Mountz A, Miyares IM. (Re)-producing Salvadoran transnational geographies, Ann Assoc Am Geogr 2002; 92(1): $125-44$.

[78] Ley D. Transnational spaces and everyday lives. Trans Inst Br Geogr 2004; 29(2): 151-64.

[79] Crang P, Dwyer C, Jackson P. Transnationalism and the spaces of commodity culture. Prog Hum Geogr 2003; 27: 438-56.

[80] Graham S. The end of geography or the explosion of place? Conceptualizing space, place and information technology. Prog Hum Geogr 1998; 22(1): 165-85.
[81] Faist T. Developing transnational social spaces: the Turkish-German example. In: Pries L, Ed. Migration and Transnational Social Spaces. Aldershot, Hants: Ashgate 1999; pp. 36-72.

[82] Levitt P. The ties that change: relations to the ancestral home over the life cycle. In: Levitt P, Waters MC, Eds. The Changing Face of Home. New York: Russell Sage Foundation 2002; pp. 123-44.

[83] Levitt P. Roots and routes: understanding the lives of the second generation transnationally. J Ethn Migr Stud 2009; 35(7): 1225-42.

[84] Levitt P. Dominicans: the prototypical transnational migrants. In: Waters M, Ueda R, Eds. The New Americans: A Guide to Immigration since 1965. Cambridge, MA: Harvard University Press 2006; pp. 399412.

[85] Kasinitz P, Mollenkopf JH, Waters MC, Eds. Becoming New Yorkers: Ethnographies of the New Second Generation. New York: Russell Sage 2004.

[86] Farley R, Alba R. The new second generation in the United States. Int Migr Rev 2002; 36(3): 669-701.

[87] Thomson M, Crul M. The second generation in Europe and the United States: How is the transatlantic debate relevant for further research on the European second generation? J Ethn Migr Stud 2007; 33(7): 102541.

[88] Piore MJ. Birds of passage: migrant labour and industrial societies. Cambridge: Cambridge University Press 1979.

[89] Portes A, Rumbaut R. Legacies: the story of the immigrant second generation. Berkeley and New York: University of California Press and Russell Sage Foundation 2001.

[90] Rumbaut R, Portes A. Ethnicities: children of immigrants in America. Berkley and New York: University of California Press and Russell Sage Foundation 2001.

[91] Vickermann M. Crosscurrents: West Indian immigrants and race. New York and Oxford: Oxford University Press 1999.

[92] Gans H. Second-generation decline: scenarios for the economic and ethnic futures of the post-1965 American Immigrants. Ethn Racial Stud 1992; 15(2): 173-92.

[93] Portes A, Zhou M. The new second-generation: segmented assimilation and its variants. Ann Am Acad Polit Soc Sci 1993; 530: 74-97.

[94] Gillborn D, Gipps C. Recent research on the achievement of ethnic minority pupils. London: Office for Standards in Education, HMSO 1996.

[95] Gillborn D, Mirza H. Educational inequality: mapping race, class and gender. London: Office for Standard in Education 2000.

[96] Wright C. The relations between teachers and Afro-Caribbean pupils: observing multiracial classrooms. In: Weiner G, Arnot M, Eds. Gender under scrutiny. Buckingham: Open University Press 1987; pp. 173-86.

[97] Sewell T. Black masculinity and schooling: How black boys survive modern schooling. Stoke on Trent: Trentham books 1997.

[98] Blaire M. Why pick on me? School exclusion and black youth. Stoke on Trent: Trentham Books 2001.

[99] Strand S. Minority ethnic pupils in the longitudinal study of young people in England (LSYPE). Department for Children, Schools and Families, London 2007.

[100] Levitt P. Keeping feet in both worlds: transnational practices and immigrant incorporation. In: Joppke C, Morawska E, Eds. Toward assimilation and citizenship: immigrants in liberal nation-states, New York: Palgrave 2003; pp. 177-94.

[101] Potter RB. Tales of two societies: young return migrants to St Lucia and Barbados. Caribb Geogr 2001; 12: 24-43.

[102] Potter RB. Citizens of descent: foreign-born and young returning nationals to St Lucia. J East Caribb Stud 2005; 30: 1-30.

[103] Potter RB. Young, gifted and back': second generation return migrants to the Caribbean. Prog Dev Stud 2005; 5(3): 213-36.

[104] Potter RB, Phillips J. Both black and symbolically white: the 'BajanBrit' return migrant as post-colonial hybrid. Ethn Racial Stud 2006; 29(5): 901-27.

[105] Potter RB, Phillips J. Mad dogs and transnational migrants?' Bajan-Brit second-generation migrants and accusations of madness. Ann Assoc Am Geogr 2006; 96(2): 586-600.

[106] Phillips J, Potter RB. Questions of friendship and degrees of transnationality among second-generation return migrants to Barbados. J Ethn Migr Stud 2009; 35(4): 669-88.

[107] Phillips J, Potter RB. Quality of life issues and second-generation migration: the case of 'Bajan-Brit returnees. Popul Space Place 2009; 15(3): 239-51.

[108] Christou A. American dreams and European nightmares: experiences and polemics of second-generation Greek-American returning migrants. J Ethn Migr Stud 2006; 32(5): 831-45. 
[109] Lee-Cunin M. My motherland or my mother's land? Return migration and the experience of young British Trinidadians. In: Potter RB, Conway D, Philips J, Eds. The experience of return migration: Caribbean perspectives. Aldershot and Burlington, USA: Ashgate 2005. pp.109-133.

[110] Wessendorf S. Roots migrants' transnationalism and 'return' among second-generation Italians in Switzerland. J Ethn Migr Stud 2007; 33(7): 1083-102.

[111] Morawska E. Immigrant transnationalism and assimilation: a variety of combinations and the analytic strategy it suggests. In: Jopke C, Morawska E, Eds. Toward assimilation and citizenship: immigrants in liberal nation-states. Basingstoke: Palgrave Macmillian 2003; pp. 133175.

[112] Peach C. The Caribbean in Europe: contrasting patterns of migration and settlement in Britain, France and the Netherlands. Research Paper in Ethnic Relations No. 15, Coventry: Centre for Research in Ethnic Relations, University of Warwick 1991.

[113] Glass R. Newcomers: The West Indians in London, (assisted by Harold Pollins). London: George Allen and Unwin Ltd 1960.

[114] Peach C. West Indian migration to Britain: a social geography. London: Oxford University Press for the Institute of Race Relations 1968.

[115] Owen D. A profile of Caribbean household and families in Great Britain. In: Goulbourne H, Chamberlain M, Eds. Caribbean families in Britain and the Trans-Atlantic World. London: Macmillian 2001; pp. 64-91.

[116] Office of National Statistics, Home Office, Census Data [Cited $23^{\text {rd }}$ March 2008] Available from: http://www.statistics.gov.uk/census2001/

[117] Peach C. Patterns of Afro-Caribbean migration and settlement in Great Britain, 1945-1981. In: Brook C, Ed. The Caribbean in Europe: Aspects of the West Indian Experience in Britain, France and the Netherlands. London, Frank Gass 1986; pp. 62-84.

[118] Gmelch G. Emigrants who come back, Part 1. The Bajan 1985; 8-9.

[119] Byron M, Condon S. A comparative study of Caribbean return migrants from Britain and France: toward context-dependent explanation. Trans Inst Br Geogr New Series 1996; 21: 91-104.

[120] Thomas-Hope EM. Return migration and its implications for the Caribbean development. In: Pastor RA, Ed. Migration and development in the Caribbean: the unexpected connection Boulder Colorado: Westview Press 1985; pp. 157-77.

[121] John G. The social worker and the young blacks. In: Triseliotis JP, Ed. Social work with coloured immigrants and their families. London: Oxford University Press 1972; pp. 78-90.

[122] Midgett DK. West Indian ethnicity in Great Britain. In: Sata HI, Du Toit BM, Eds. Migration and development: implications for ethnic identity and political conflict. The Hague: Mouton Publishers 1975; pp. $57-82$.

[123] Chamberlain M. Caribbean migration: globalized identities. London and New York: Routledge 1998.

[124] Lloyd Evans S, Bowlby S. Crossing boundaries: racialized gendering and the labour market experiences of Pakistani migrant women in Britain. Women Stud Int Forum 2000; 23(4): 461-74.

[125] Gilroy P. The Black Atlantic: modernity and double consciousness. London: Verso 1993.

[126] Potter RB, Phillips J. The past is still right here in the present": secondgeneration Bajan-Brit transnational migrants' views on issues relating to race and colour class. Environ Plann D 2008; 26, 123-45

[127] Anwar M. The myth of return: Pakistanis in Britain. London: Heinemann Educational 1979.

[128] Chamberlain M. Brothers and sisters, uncles and aunts: a lateral perspective on Caribbean families. In: Silva EB, Smart C, Eds. The new family? London: Sage 1999; pp. 129-142.

[129] Chamberlain M. Family love in the Diaspora: migration and the anglocaribbean experience. New Brunswick, NJ: Transaction Publishers 2006.
[130] Fog Olwig K. New York as a locality in a global family network. In: Foner N, Ed. Islands in the City: West Indian migration to New York, Berkeley. Los Angeles and London: University of California Press 2001; pp. 142-160.

[131] Fog Olwig K. Transnational socio-cultural systems and ethnographic research: views from an extended field site. Int Migr Rev 2003; 37(3): 787-11.

[132] Goulbourne H, Chamberlain M, Eds. Caribbean families in Britain and the trans-atlantic world. London and Oxford: Macmillan Press, Caribbean Studies 2001

[133] Ho CTG. The internationalization of kinship and the feminization of Caribbean migration: the case of Afro-Trinidadian immigrants in Los Angeles. Hum Organ 1993: 52(1): 32-40.

[134] Carnegie CV. Strategic flexibility in the West Indies. Caribb Rev 1982; 11(1): 11-13, 54.

[135] Conway D. Caribbean migrants: opportunistic and individualistic sojourners. Hanover, New Hampshire: Universities Field Staff International, UFSI Report 1986; No. 24.

[136] Conway D. Conceptualizing contemporary patterns of Caribbean international mobility. Caribb Geogr 1988; (2): 145-63.

[137] Barrow C. Family in the Caribbean: themes and perspectives. Kingston, Jamaica: Ian Randle Publishers 1996.

[138] Clarke E. My mother who fathered me: a study of the families of three selected communities in Jamaica. Kingston, Jamaica: The Press, the University of the West Indies 1957.

[139] Thompson P, Bauer E. Jamaican transnational families: points of pain and sources of resilience. WADABAGEI: J Caribb Diaspora 2000; 3(2): 1- 36 .

[140] Wiltshire R. The Caribbean transnational family. UNESCO/ISER Seminar on Changing Family Patterns and Women's role in the Caribbean, Eastern Caribbean sub-regional Seminar. The University of the West Indies, Cave Hill, Barbados 1986.

[141] Davidoff L, Hall C, Eds. Family fortunes: men and women of the English middle class 1780-185. London: Routledge 1987.

[142] Potter RB, Barker D, Conway C, Klak T. The contemporary Caribbean. London and New York: Pearson-Prentice Hall 2004.

[143] Gottlieb B. The family in the western world. New York: Oxford 1993.

[144] Chamberlain M. Family narratives and migration dynamics. New West Indies Guide/Nieue West-Indische Gids 1995; 69(3/4): 253-275.

[145] Scotland STC. Caribbean transnational childhood: the children left behind by migration. The $7^{\text {th }}$ Annual SALISES Conference, Social Policy Challenges in the Post-Independence Era. The University of the West Indies, Cave Hill, Barbados 2007.

[146] Conway D, Potter RB, St Bernard G. Dual citizenship or dual identity?: Does 'transnationalism' supplant 'nationalism' among returning Trinidadians? Global Netw 2008; 8(4): 373-397.

[147] Goulbourne, H. Some Introductory Remarks. In: Goulbourne H, Ed. Black Politics in Britain, Aldershot: Avebury 1990; pp. 1-14.

[148] Reynolds T. Caribbean families, social capital and young people's diasporic identities. Ethn Racial Stud 2006; 29(6): 1087-1103.

[149] Reynolds T, Zontini E. Families, social capital and ethnic identities of Caribbeans, South Asians and South Europeans. In: Goulbourne H, Ed. Families and Social Capital ESRC Research Group Working Paper No. 20, London South Bank University 2006 [Cited 2007 December 14]. Available from: http://www.lsbu.ac.uk/families/workingpapers/famil ieswp20.pdf

[150] Layton-Henry Z. Transnational communities, citizenship and AfricanCaribbeans in Birmingham. WPTC-02-03. [Cited 2007 November 14]. Available from: http://www.transcomm.ox.ac.uk/working\%20papers/ WPTC-02-07\%20LaytonHenry.pdf

[151] Potter RB, Conway D. The development potential of Caribbean young return migrants: "Making a difference back home...". In: van Naerssen T, Spann E, Zoomers A, Eds. Global Migration and Development. New York and Abingdon, Oxford: Routledge 2007: pp. 213-230. 